Agro-Science Journal of Tropical Agriculture, Food, Environment and Extension Volume 12 Number 2 Mav 2013 pp. 28 - 34

ISSN 1119-7455

\title{
THE EFFECTS OF CONTINUOUS CROPPING AND FALLOWING ON THE CHEMICAL PROPERTIES OF AN ULTISOL IN NSUKKA, NIGERIA
}

\author{
${ }^{1}$ Asadu, C.L.A. and L. D. Ekeleman \\ Department of Soil Science, University of Nigeria, Nsukka, Nigeria \\ ${ }^{1}$ E-mail addresses: charlesasadu@yahoo.com; Charles.asadu@unn.edu.ng (corresponding author); \\ leonardekeleman@yahoo.com.
}

\begin{abstract}
In this study, soil chemical properties were determined in a cleared forestland continuously grown to cassava (Manihot esculenta Crantz), pigeon pea (Cajanus cajan), maize (Zea mays) and their combination for seven years and from then was fallowed for ten years. Soil samples were also collected from the adjacent cleared uncultivated but fallowed plots as well as the original forestland and analyzed. The objective was to compare nutrient recovery capacity as related to land use history under natural fallow. The study showed that the solely cassava plots were able to recover more available $\mathrm{P}$, exchangeable $\mathrm{Mg}, \mathrm{CEC}$ and had the highest $\mathrm{pH}$ value during the fallow period. Plots grown to sole pigeon pea were able to recover more organic matter, exchangeable $\mathrm{K}$, exchangeable Na and exchangeable acidity than other plots. The control plot had the highest total $N$, while, the $M+P$ plots recovered more exchangeable Ca. Compared to the year the forest was cleared, OM, CEC, exchangeable $\mathrm{Ca}, \mathrm{Mg}$, and $\mathrm{Na}$ were able to recover to about their original values, while, total $\mathrm{N}$, exchangeable $\mathrm{K}$ and available $P$ could not. Thus, soil nutrient recovery through natural fallow is related to previous cropping history but a period of ten years may be enough for some of the nutrients to recover their original levels.
\end{abstract}

Key words: cropping system, fallowing, nutrient recovery, ultisol

\section{INTRODUCTION}

The geometric increases in human populations in tropical Africa (Nigeria inclusive) has given rise to the need for agricultural practices to be shifted from traditional extensive system of shifting cultivation to continuous cropping systems (Aweto, 1981) in the form of year round intercropping or monocropping with less than 3 months rest period (no fallowing).

The soils of Nsukka area in Eastern Nigeria are generally derived from the residua of false-bedded sand-stone or uppercoal measure formations and these geological formations gave the soils their sandy and clayey characteristics respectively with only low to medium inherent nutrient levels (Akamigbo and Asadu, 1983; Asadu, 1990). Thus, soil fertility maintenance is a major concern and organic matter contributes over $60 \%$ of the CEC of the soils in the entire sub-Saharan Africa (Asadu and Akamigbo, 1990; Asadu et al,. 1997).

In traditional farming systems, farmers use bush fallow, plant residues, household refuse, animal manures and other organic nutrient sources to maintain soil fertility and soil organic matter. Although this reliance on biological nutrient sources for soil fertility regeneration is adequate with low cropping intensity, it becomes unsustainable with more intensive cropping unless mineral fertilizers are applied (Mulongey and Merck, 1993). It is therefore important to know that during cropping, there is lowering of soil fertility and susceptibility to erosion; this is characteristic of continuous cropping systems because the soil is exposed for long and unprotected from damaging rainfall of high intensity and long duration. Flinck (1973) viewed that the reduced yields in various lands in the tropics, which become apparent, even after a year or two of cultivation are caused by a lowering of soil fertility and thus pose many constraints on intensive food crop production in tropical Africa. Thus, it has long been predicted that if adequate care was not taken, tropical soil would be subjected to degradation and the natural roles of the fertile soil would not be

http://dx.doi.org/10.4314/as.v12i2.4 
achieved but fallowing might help to control this degradation (Lal, 1987).

Forests are complex ecosystem that consists of mainly trees that support a myriad of life forms. The plants provide a protective canopy that lessens the impact of raindrops on the soil, thereby reducing erodibility. The layer of leaves that falls around the trees prevents run-off and allows percolation. Dead plants decompose to form humus and organic matter that hold soil water and provide nutrients to the soil. Roots help to hold the soil in place (FAO, 1983).

Continuous cropping has major impacts on soil properties, both chemical and physical (Lal, 1984). The burning of the dried surface trash expels many of the accumulated nutrients, whilst exposure of the bare soil surface to raindrop impact results in soil structural degradation and accelerated erosion, particularly on sloping lands (Hudson, 1981).

Continuous cropping leads to the decrease in soil organic matter within the first few years under cropping, and this becomes more pronounced with time resulting in serious nutrient losses and low CEC (Kang and Juo, 1983). Changes in agricultural practices such as change in crop varieties, application of mineral fertilizers and organic manures, rotation and tillage practices influence how much and at what rate carbon is stored in or released from soils (Anikwe, 2010).

Fallowing is a process where land is left for a period of time without being cultivated to correct soil degradation due to continuous cropping. It is important in building soil chemical properties but it is hardly acceptable where human population density is high. At the outskirts of the study area a lot of land is still under fallow. Therefore, the aim of this study was to estimate the minimum period a piece of land with cropping history could be fallowed for it to recover its original nutrient level under natural fallow.

\section{MATERIALS AND METHODS \\ Background of the Study}

This paper is from an on-going long-term research on the sustainability of selected common cropping systems practiced by most farmers in eastern Nigeria. More details on this study can be obtained from the following journal publications; Dixon and Asadu 2001; Asadu and Dixon 2002; Asadu et al. 2002; Asadu and Dixon 2005; Asadu et al. 2010; Asadu et al. 2013 and Asadu et al. 2014. The summary may be given as follows: In 1998, after clearing the forest and before embarking on the establishment of the trials, soil samples were collected at random to assess the variability in the soil properties in order to ascribe subsequent variations to treatments applied. The forest was cleared in January 1998 and accumulated large debris and dry matter were burnt and the stumps were removed manually by digging them up. The crops were planted at a spacing of $1 \mathrm{~m} \times 1 \mathrm{~m}$ on ridges made with hoes. The cultivated plots were arranged in a Randomized Complete Block Design (RCBD). Three treatments applied included solely cassava (Manihot esculenta Crantz) (SC), solely pigeon pea (Cajanus cajan) (SP), solely maize (Zea mays) (SM) and their combination $(\mathrm{M}+\mathrm{P}, \mathrm{C}+\mathrm{P}$ and $\mathrm{C}+\mathrm{M}+\mathrm{P})$. The selection of the crops was based on the prior knowledge of the most common staple food crops grown by the local farmers. Each plot $(8 \mathrm{~m} \times 5 \mathrm{~m})$ contained one treatment and was replicated three times. These crops and their combinations were continuously grown in their respective plots for seven years (May 1998-May 2005). Incorporation of crop residues emanating the respective plots was the only soil amendment applied. Before crops were planted during the seven years of cultivation and ten years of fallow, loose soil samples were collected once a year from three random locations on each replicate plot at a depth of $0-20 \mathrm{~cm}$ using an auger. The fallow land was covered predominantly by Siam weed (Chromolaena odorata) and few grasses such as Guinea grass (Panicum maximum) and Elephant grass (Pennisetum purpureum). In 2014, data were also obtained from cleared uncultivated but fallowed plots as well as the adjacent undisturbed forest.

\section{Study Area}

Nsukka is located by latitude $6^{\circ} 52^{\prime} 3$ ' $\mathrm{N}$ and longitude $7^{\circ} 23$ ' 2" E within the derived savanna zone of southeastern Nigeria. It is on an average elevation of $447 \mathrm{~m}$ above sea level. The major soils were derived from the disintegrated rock materials of either false-bedded sandstone or upper-coal measures (Asadu, 1990) and these respectively gave rise to sandy and clayey soils found in the lower and upper slopes (Akamigbo and Asadu, 1983). These soils are exposed to high temperatures and rainfall of high intensity and erosivity which results in erosion and leaching. Two climatic seasons are predominant in this region - rainy and dry seasons. The mean annual rainfall is about $1550 \mathrm{~mm}$ with $85 \%$ of this falling between April and October. The average minimum and maximum temperature values are $22^{\circ} \mathrm{C}$ and $30^{\circ} \mathrm{C}$ respectively. The relative humidity is about $60 \%$ on the average over the years (Asadu et al., 2002).

\section{Laboratory Analyses}

The following analyses were carried out on the soil samples collected from the field: soil $\mathrm{pH}$, which was determined according to the method described by Juo (1979); organic carbon (Walkley and Black, 1934); total nitrogen by the Kjeldahl method (Bremner Mulvaney, 1982); available phosphorus (Bray and Kurtz, 1945); exchangeable calcium and magnesium, potassium, sodium and cation exchange capacity 
(Thomas, 1982) and exchangeable acidity (McLean, 1965). The values of organic carbon were converted to organic matter by multiplying with the factor 1.724 .

\section{Statistical Analyses}

Statistical Analysis Systems (SAS, 1985), version 8 was used for the Analysis of Variance (ANOVA) and the difference between treatment means was determined by Least Significant Difference (LSD). For 2014 data, the LSD values for comparing the effect of the cropping systems were determined first, then those to compare with the control, Ep (cleared uncultivated but fallowed) were obtained, and then those to compare with the original forest data were obtained as the overall LSD values.
RESULTS AND DISCUSSION

Variability of Soil Chemical Properties of cleared forest before cultivation

Most of the soil nutrients were uniformly distributed across the field prior to the establishment of the trial (Table 1). Only exchangeable $\mathrm{Na}$ was highly variable (CV> 60\%); available P (Av. P) and exchangeable $\mathrm{Ca}$ and $\mathrm{Mg}$ were moderately variable. This implied that any change in the nutrient elements in the course of the experiment would not be attributed to the inherent variations across the field but to the different cropping systems, fallow or deviation from the current values obtained from the original forestland.

Table 1: Measure of variability in soil chemical properties in the cleared forest before cultivation.

\begin{tabular}{|c|c|c|c|c|c|c|c|c|c|c|}
\hline & $\begin{array}{l}\mathrm{pH} \\
-\mathrm{g} \\
\end{array}$ & SOM & Total N & Ex.Ca & Ex. Mg & $\begin{array}{r}\text { Ex. K } \\
g^{-1} \\
\end{array}$ & Ex. Na & EA & CEC & $\begin{array}{l}\text { Av. P } \\
\left(\mathrm{mgkg}^{-1}\right)\end{array}$ \\
\hline Mean & 4.33 & 2.28 & 0.12 & 0.82 & 0.43 & 0.15 & 0.22 & 0.93 & 2.56 & 11.48 \\
\hline SD & 0.07 & 0.36 & 0.02 & 0.31 & 0.13 & 0.04 & 0.14 & 0.08 & 0.25 & 4.12 \\
\hline $\mathrm{CV}(\%)$ & 1.62 & 15.79 & 16.67 & 37.80 & 30.23 & 26.67 & 63.64 & 8.60 & 9.77 & 35.89 \\
\hline
\end{tabular}

$\mathrm{SOM}=$ soil organic matter, Ex. $\mathrm{Ca}=$ exchangeable calcium, Ex. $\mathrm{Mg}=$ exchangeable magnesium, Ex. $\mathrm{K}=$ exchangeable potassium, Ex. $\mathrm{Na}=$ exchangeable sodium, $\mathrm{EA}=$ exchangeable acidity, $\mathrm{CEC}=$ cation exchange capacity, $\mathrm{Av} . \mathrm{P}=$ available phosphorus, $\mathrm{SD}=$ standard deviation, $\mathrm{CV}=$ coefficient of variation

Source: Asadu et al, 2013.

Table 2: Mean effects of fallow on cropped plots after ten years

\begin{tabular}{|c|c|c|c|c|c|}
\hline \multirow[b]{2}{*}{ Treatment } & \multicolumn{2}{|c|}{ pH } & \multirow{2}{*}{$\begin{array}{l}\text { OM } \\
\left(\mathrm{g} \mathrm{kg}^{-1}\right)\end{array}$} & \multirow{2}{*}{$\begin{array}{l}\text { TN } \\
\left(\mathrm{g} \mathrm{kg}^{-1}\right)\end{array}$} & \multirow{2}{*}{$\begin{array}{l}\text { Av. P } \\
\left(\mathrm{mg} \mathrm{kg}^{-1}\right)\end{array}$} \\
\hline & $\mathrm{H}_{2} \mathrm{O}$ & KCl & & & \\
\hline $\mathrm{SC}$ & 4.37 & 3.73 & 22.7 & 0.67 & 11.81 \\
\hline $\mathrm{C}+\mathrm{M}+\mathrm{P}$ & 4.37 & 3.67 & 23.5 & 0.83 & 5.91 \\
\hline $\mathrm{C}+\mathrm{P}$ & 4.27 & 3.63 & 23.3 & 1.03 & 9.33 \\
\hline SM & 4.37 & 3.60 & 21.6 & 0.57 & 4.66 \\
\hline $\mathrm{M}+\mathrm{P}$ & 4.23 & 3.57 & 26.1 & 1.20 & 7.15 \\
\hline SP & 4.33 & 3.57 & 29.6 & 1.13 & 7.77 \\
\hline $\operatorname{LSD}_{(0.05)}$ & 0.180 & 0.166 & 7.01 & 0.50 & 13.550 \\
\hline Interpretation & $\mathrm{ns}$ & $\mathrm{ns}$ & $\mathrm{ns}$ & $\mathrm{p}<0.05$ & $\mathrm{~ns}$ \\
\hline
\end{tabular}

$\mathrm{SC}=$ solely cassava, $\mathrm{SM}=$ solely maize, $\mathrm{SP}=$ solely pigeon pea, $\mathrm{C}+\mathrm{P}=$ cassava + pigeon pea, $\mathrm{C}+\mathrm{M}+\mathrm{P}=\mathrm{cassava}+$ maize + pigeon pea, $\mathrm{M}+\mathrm{P}=$ maize + pigeon pea, $\mathrm{OM}=$ organic matter, $\mathrm{TN}=$ total nitrogen, Av. $\mathrm{P}=$ available phosphorus, $\mathrm{LSD}(0.05)=$ least significant difference at $5 \%$, ns $=$ not significantly differ

Table 3: Mean effects of fallow on cropped plots compared with control after ten years

\begin{tabular}{|c|c|c|c|c|c|}
\hline \multirow[b]{2}{*}{ Treatment } & \multicolumn{2}{|c|}{ pH } & \multirow{2}{*}{$\begin{array}{l}\text { SOM } \\
\left(\mathrm{g} \mathrm{kg}^{-1}\right)\end{array}$} & \multirow{2}{*}{$\begin{array}{l}\text { TN } \\
\left(\mathrm{g} \mathrm{kg}^{-1}\right)\end{array}$} & \multirow{2}{*}{$\begin{array}{l}\text { Av. P } \\
\left(\mathrm{mg} \mathrm{kg}^{-1}\right)\end{array}$} \\
\hline & $\mathrm{H}_{2} \mathrm{O}$ & KCl & & & \\
\hline $\mathrm{SC}$ & 4.37 & 3.73 & 2.27 & 0.67 & 11.81 \\
\hline $\mathrm{C}+\mathrm{M}+\mathrm{P}$ & 4.37 & 3.67 & 2.35 & 0.83 & 5.91 \\
\hline $\mathrm{C}+\mathrm{P}$ & 4.27 & 3.63 & 2.33 & 1.03 & 9.33 \\
\hline SM & 4.37 & 3.60 & 2.16 & 0.57 & 4.66 \\
\hline $\mathrm{M}+\mathrm{P}$ & 4.23 & 3.57 & 2.61 & 0.120 & 7.15 \\
\hline SP & 4.33 & 3.57 & 2.96 & 1.13 & 7.77 \\
\hline$E_{P}$ & 4.37 & 3.73 & 2.68 & 1.27 & 6.21 \\
\hline $\operatorname{LSD}_{(0.05)}$ & 0.172 & 0.162 & 1.214 & 0.67 & 11.75 \\
\hline interpretation & ns & ns & $\mathrm{ns}$ & $\mathrm{P}<0.05$ & ns \\
\hline
\end{tabular}

$\mathrm{SC}=$ solely cassava, $\mathrm{SM}=$ solely maize, $\mathrm{SP}=$ solely pigeon pea, $\mathrm{C}+\mathrm{P}=$ cassava + pigeon pea, $\mathrm{C}+\mathrm{M}+\mathrm{P}=$ cassava + maize + pigeon pea, $\mathrm{M}+\mathrm{P}=$ maize + pigeon pea, $\mathrm{Ep}=$ Control plot, $\mathrm{SOM}=$ soil organic matter, $\mathrm{TN}=$ total nitrogen, $\mathrm{Av} . \mathrm{P}=$ available phosphorus, $\mathrm{LSD}(0.05)=$ least significant difference at $5 \%, \mathrm{~ns}=$ not significantly different 


\section{Effect of Fallow on Soil Chemical Properties}

Table 2 shows that the mean total $\mathrm{N}$ values were significantly affected $(\mathrm{p}<0.05)$ after ten years of fallow as related to cropping history. The highest values $(1.2 \mathrm{~g}$ $\mathrm{kg}^{-1}$ ) obtained from plots previously grown to $\mathrm{M}+\mathrm{P}$ was significantly higher than those from plots previously grown to SM and SC. Again the value from plots previously grown to SP was significantly higher than that from plots previously grown to SM. The $\mathrm{pH}$, SOM, and available $\mathrm{P}$ values were not significantly different indicating that after ten years the cropping history effect was statistically the same.

Table 3 shows that when data from the control plots (Ep) were combined with those from cropped plots only total $\mathrm{N}$ was significantly affected $(\mathrm{p}<0.05)$ while differences in the other parameters were not statistically significant. The mean value obtained from Ep was significantly higher than that from only the plots previously grown to SM

The overall mean effects shown in table 4 indicate that the $\mathrm{pH}(\mathrm{KCl})$ obtained from plots previously grown to $\mathrm{SC}$ and Ep were significantly higher $(\mathrm{p}<0.05)$ than those from plots previously grown to $\mathrm{M}+\mathrm{P}$ and SP. Again the mean value from Ep was significantly $(\mathrm{p}<$ $0.05)$ higher than that from plots previously grown to SM. The trends in total N, SOM and available P were similar to that obtained when cropped plots were combined with the control (Table 2).

Table 4: The overall mean effects of fallow on cropped, control and original forest

\begin{tabular}{|c|c|c|c|c|c|}
\hline \multirow[b]{2}{*}{ Treatment } & \multicolumn{2}{|c|}{ pH } & \multirow{2}{*}{$\begin{array}{l}\text { SOM } \\
\left(\mathrm{g} \mathrm{kg}^{-1}\right)\end{array}$} & \multirow{2}{*}{$\begin{array}{l}\text { TN } \\
\left(\mathrm{g} \mathrm{kg}^{-1}\right)\end{array}$} & \multirow{2}{*}{$\begin{array}{l}\text { Av. P } \\
\left(\mathrm{mg} \mathrm{kg}^{-1}\right)\end{array}$} \\
\hline & $\mathrm{H}_{2} \mathrm{O}$ & $\mathrm{KCl}$ & & & \\
\hline SC & 4.37 & 3.73 & 2.27 & 0.067 & 11.81 \\
\hline $\mathrm{C}+\mathrm{M}+\mathrm{P}$ & 4.37 & 3.67 & 2.35 & 0.083 & 5.91 \\
\hline $\mathrm{C}+\mathrm{P}$ & 4.27 & 3.63 & 2.33 & 0.103 & 9.33 \\
\hline SM & 4.37 & 3.60 & 2.16 & 0.057 & 4.66 \\
\hline $\mathrm{M}+\mathrm{P}$ & 4.23 & 3.57 & 2.61 & 0.120 & 7.15 \\
\hline SP & 4.33 & 3.57 & 2.96 & 0.113 & 7.77 \\
\hline$E_{P}$ & 4.37 & 3.73 & 2.68 & 0.127 & 6.21 \\
\hline Forest & 4.33 & 3.60 & 2.72 & 0.103 & 7.77 \\
\hline $\operatorname{LSD}_{(0.05)}$ & 0.157 & 0.146 & 1.089 & 0.063 & 10.50 \\
\hline Interpretation & $\mathrm{ns}$ & ns & $\mathrm{ns}$ & $\mathrm{p}<0.05$ & Ns \\
\hline
\end{tabular}

Table 5: Mean effects of fallow on cropped plots after ten years on exchangeable Cations and CEC

\begin{tabular}{|c|c|c|c|c|c|c|c|}
\hline Treatment & $\mathrm{Ca}^{2+}$ & $\mathrm{Mg}^{2+}$ & $\mathrm{Na}^{+}$ & $\mathbf{K}^{+}$ & $\mathrm{Al}^{3+}$ & $\mathbf{H}^{+}$ & CEC \\
\hline \multicolumn{8}{|c|}{$\left(\mathrm{Cmo1kg}^{-1}\right)$} \\
\hline $\mathrm{SC}$ & 1.33 & 2.00 & 0.23 & 0.14 & 1.07 & 4.67 & $\overline{10} 10.13$ \\
\hline $\mathrm{C}+\mathrm{M}+\mathrm{P}$ & 1.33 & 1.73 & 0.28 & 0.13 & 1.07 & 4.80 & 6.93 \\
\hline $\mathrm{C}+\mathrm{P}$ & 1.47 & 0.93 & 0.26 & 0.16 & 1.33 & 3.60 & 8.00 \\
\hline SM & 1.47 & 0.80 & 0.28 & 0.17 & 1.20 & 3.87 & 8.00 \\
\hline $\mathrm{M}+\mathrm{P}$ & 2.13 & 0.56 & 0.28 & 0.16 & 1.20 & 4.67 & 7.20 \\
\hline SP & 2.00 & 1.07 & 0.29 & 0.17 & 1.33 & 4.67 & 8.53 \\
\hline $\operatorname{LSD}_{(0.05)}$ & 1.205 & 1.178 & 0.056 & 0.042 & 0.601 & 1.335 & 6.239 \\
\hline Interptn & ns & $\mathrm{P}<0.05$ & $\mathrm{P}<0.05$ & ns & ns & Ns & Ns \\
\hline
\end{tabular}

$\mathrm{SC}=$ solely cassava, $\mathrm{SM}=$ solely maize, $\mathrm{SP}=$ solely pigeon pea, $\mathrm{C}+\mathrm{P}=$ cassava + pigeon pea, $\mathrm{C}+\mathrm{M}+\mathrm{P}=$ cassava + maize + pigeon pea, $\mathrm{M}+\mathrm{P}=$ maize + pigeon pea, $\mathrm{CEC}=$ cation exchange capacity, $\mathrm{LSD}_{(0.05)}=$ least significant difference at $5 \%$, ns $=$ not significantly different 
Table 5 shows that the mean exchangeable $\mathrm{Mg}$ was significantly higher $(\mathrm{p}<0.05)$ in plots previously grow to $\mathrm{SC}$ and $\mathrm{C}+\mathrm{M}+\mathrm{P}$ than in plots previously grown to $\mathrm{M}+\mathrm{P}$ but similar to other values. The mean values of exchangeable $\mathrm{Na}$ was significantly higher $(\mathrm{p}<0.05)$ in plots previously grown to SP than in plots previously grown to SC but similar to others (Table 5).The differences in the exchangeable cations and acidity as well as CEC were not statistically significant. The implication is that after ten years of fallow, cropping history appeaed to have no significant effect of these parameters.

From Table 6 only the mean value of exchangeable $\mathrm{Na}$ obtained from plots previously grown to SP was significantly higher than that obtained from the plots previously grown to SC. The differences between the other parameters were not significant

Table 6: Mean effects of fallow on cropped plots compared with control after ten years on Exchangeable Cations and CEC

\begin{tabular}{|c|c|c|c|c|c|c|c|}
\hline Treatment & $\mathrm{Ca}^{2+}$ & $\mathrm{Mg}^{2+}$ & $\mathrm{Na}^{+}$ & $\mathbf{K}^{+}$ & $\mathrm{Al}^{3+}$ & $\mathbf{H}^{+}$ & CEC \\
\hline \multicolumn{8}{|c|}{$\left(\mathrm{Cmol} \mathrm{kg}^{-1}\right)$} \\
\hline SC & 1.33 & 2.00 & 0.23 & 0.14 & 1.07 & 4.67 & 10.13 \\
\hline $\mathrm{C}+\mathrm{M}+\mathrm{P}$ & 1.33 & 1.73 & 0.28 & 0.13 & 1.07 & 4.80 & 6.93 \\
\hline $\mathrm{C}+\mathrm{P}$ & 1.47 & 0.93 & 0.26 & 0.16 & 1.33 & 3.60 & 8.00 \\
\hline SM & 1.47 & 0.80 & 0.28 & 0.17 & 1.20 & 3.87 & 8.00 \\
\hline $\mathrm{M}+\mathrm{P}$ & 2.13 & 0.56 & 0.28 & 0.16 & 1.20 & 4.67 & 7.20 \\
\hline SP & 2.00 & 1.07 & 0.29 & 0.17 & 1.33 & 4.67 & 8.53 \\
\hline $\mathrm{E}_{\mathrm{P}}$ & 1.73 & 1.33 & 0.28 & 0.15 & 1.20 & 4.53 & 8.80 \\
\hline $\operatorname{LSD}_{(0.05)}$ & 1.114 & 1.481 & 0.052 & 0.053 & 0.926 & 1.257 & 5.596 \\
\hline interprtn & ns & $\mathrm{ns}$ & $\mathrm{P}<0.05$ & ns & ns & ns & ns \\
\hline
\end{tabular}

$\mathrm{SC}=$ solely cassava, $\mathrm{SM}=$ solely maize, $\mathrm{SP}=$ solely pigeon pea, $\mathrm{C}+\mathrm{P}=$ cassava + pigeon pea, $\mathrm{C}+\mathrm{M}+\mathrm{P}=\mathrm{cassava}+\mathrm{maize}+$ pigeon pea, $\mathrm{M}+\mathrm{P}=$ maize + pigeon pea, $\mathrm{Ep}=$ control plot, $\mathrm{CEC}=$ cation exchange capacity, $\mathrm{LSD}_{(0.05)}=$ least significant difference at $5 \%$, ns $=$ not significantly different

Table 7: The overall mean effects of fallow on cropped, control and original forest on exchangeable Cations and CEC

\begin{tabular}{|c|c|c|c|c|c|c|c|}
\hline $\begin{array}{l}\text { Treatme } \\
\text { nt }\end{array}$ & $\mathrm{Ca}^{2+}$ & $\mathrm{Mg}^{2+}$ & $\mathrm{Na}^{+}$ & $\mathbf{K}^{+}$ & $\mathbf{A l}^{3+}$ & $\mathbf{H}^{+}$ & CEC \\
\hline \multicolumn{8}{|c|}{$\left(\mathrm{Cmo1} \mathrm{kg}^{-1}\right)$} \\
\hline $\mathrm{SC}$ & 1.33 & 2.00 & 0.23 & 0.14 & 1.07 & 4.67 & 9.44. \\
\hline $\mathrm{C}+\mathrm{M}+\mathrm{P}$ & 1.33 & 1.73 & 0.28 & 0.13 & 1.07 & 4.80 & 9.34 \\
\hline $\mathrm{C}+\mathrm{P}$ & 1.47 & 0.93 & 0.26 & 0.16 & 1.33 & 3.60 & 7.75 \\
\hline SM & 1.47 & 0.80 & 0.28 & 0.17 & 1.20 & 3.87 & 7.79 \\
\hline $\mathrm{M}+\mathrm{P}$ & 2.13 & 0.56 & 0.28 & 0.16 & 1.20 & 4.67 & 9.0 \\
\hline SP & 2.00 & 1.07 & 0.29 & 0.17 & 1.33 & 4.67 & 9.53 \\
\hline $\mathrm{E}_{\mathrm{P}}$ & 1.73 & 1.33 & 0.28 & 0.15 & 1.20 & 4.53 & 0.22 \\
\hline Forest & 2.13 & 1.47 & 0.27 & 0.10 & 0.93 & 4.27 & 9.17 \\
\hline $\operatorname{LSD}_{(0.05)}$ & 1.002 & 1.331 & 0.061 & 0.067 & 0.906 & 1.138 & 4.988 \\
\hline Interpret & ns & $\mathrm{P}<0.05$ & ns & $\mathrm{P}<0.05$ & $\mathrm{~ns}$ & $\mathrm{P}<0.05$ & ns \\
\hline
\end{tabular}

$\mathrm{SC}=$ solely cassava, $\mathrm{SM}=$ solely maize, $\mathrm{SP}=$ solely pigeon pea, $\mathrm{C}+\mathrm{P}=$ cassava + pigeon pea, $\mathrm{C}+\mathrm{M}+\mathrm{P}=\mathrm{cassava}+\mathrm{maize}+$ pigeon pea, $\mathrm{M}+\mathrm{P}=$ maize + pigeon pea, $\mathrm{Ep}=$ control plot, $\mathrm{CEC}=$ cation exchange capacity, $\mathrm{LSD}{ }_{(0.05)}=$ least significant difference at $5 \%, \mathrm{~ns}=$ not significantly different

The overall statistical results (Table 7) shows that the mean value of exchangeable $\mathrm{Mg}$ from plots previously grown to SC was significantly higher than that from plots previously grown to $\mathrm{M}+\mathrm{P}$. The mean exchangeable $\mathrm{K}$ from both plots previously grown to SM and SP were similar to others but significantly higher than that from the original forest. Exchangeable $\mathrm{H}$ was significantly higher in $\mathrm{C}+\mathrm{M}+\mathrm{P}$ plots than in $\mathrm{C}+\mathrm{P}$ plots; others were statistically similar (Table 7)

\section{CONCLUSION}

From this study fallowing a piece of agricultural land after continuous cultivation helps the soil regain its lost nutrients but not at the same rate. For seven-year period of continuous cultivation at least ten years of fallow is needed. The study also revealed that in the tenth year of fallow, cropping history only affected total $\mathrm{N}$, exchangeable $\mathrm{Mg}$ and $\mathrm{Na}$. Compared to the 
control and original forest the differences were minimal when compared to the various cropped plots. The statistical similarities of the nutrient contents from

\section{REFERENCES}

Akamigbo, F.O.R. and Asadu, C.L.A., 1983. The influence of parent materials on soils of south eastern Nigeria. East African Agricultural and forestry Journal. 48: 81-91.

Anikwe, M.A.N., 2010. Carbon storage in soil of south eastern Nigeria under different management practices. Carbon Balance Management Journal:http://www.cbmjournal.com/content/5 /1/5,2010.

Asadu, C.L.A., 1990. A Comparative characterization of two foot-slope soils in Nsukka area of Eastern Nigeria. Soil Science, USA. Vol. 150: 527-534.

Asadu C.L.A 2002. Fluctuations in the characteristics of an important short tropical season, 'august break' in eastern Nigeria. Discovery and Innovation. 14 (1\&2): 92-101.

Asadu, C.L A. and A.G.O. Dixon 2002.Comparative effects of continuous cultivation of seven crop combinations on soil physicochemical properties in two oils of different land use history in eastern Nigeria. Communications in Soil Science and Plant Analysis 33(19\&20): 3545-3566.

Asadu, C. L. A. and A.G. O. Dixon 2005.Soil nutrient and cassava yield variations under continuous cultivation of three-crop mixtures in eastern Nigeria .Tropical Agric. 82 (1): 1-7

Asadu, C.L.A. and F.O.R. Akamigbo, 1990. Relative contributions of organic matter and clay fractions to cation-exchange capacity (CEC) of soils in Southeastern Nigeria. Samara J. Agric. Res. 7:17-23. Nigeria

Asadu, C.L.A., J. Diels and B. Vanluawe. 1997. A comparison of the contributions of clay, silt and organic matter to the effective CEC of soils in sub-Saharan Africa. Soil Science 162: 785-794.

Asadu, C.L.A, A.G.O. Dixon and R. Okechukwu 2002. Comparative evaluation of the contributions of soil physicochemical properties to variations in the yields of four major staple food crops in eastern Nigeria. Soils \& Tillage Research. 65 (2): 141-155.

Asadu, C. L. A.; S. C. Obasi, and A. G. O. Dixon. 2010. Variations in Soil Physical Properties in a Cleared Forestland Continuously Cultivated for Seven Years in Eastern Nsukka, Nigeria Communications in Soil Science and Plant Analysis, 41: 123 - 132. the fallowed plots with those of the undisturbed forest land showed that ten years was ideal for most of the nutrients to recover their original status.

Asadu, C. L. A., Obasi, S. C., Dixon, A. G. O., Ugele, N. and Chibuike, G. U. 2013. Soil fertility recovery in clearedforestland cultivated and fallowed for seven years. J. Agriculture and Biodiversity Research 2 (5):110-116.

Asadu, C.L.A., Chibuike, G.U., A.G.O. Dixon. 2014. Micronutrients availability in a cleared forestland after seven years of continuous cultivation and eight years of natural fallow in an alfisol, Eastern Nigeria. Sci. Agri. 4 (2), 8690

Aweto O.A., 1981. Fallowing and soil, soil fertility restoration in south western Nigeria. Malaysian Journal Tropical Geogr., 3: 1-7.

Black, C.A, 1965. Methods of soil analysis. Part I, American Society of Agronomy. Madison, Wisconsin, USA. 1572p.

Bouyoucos, G.J., 1962. Hydrometer method improvement for making particle size analysis of soils. Agron. J. 5179-186.

Bray, K.H. and Kurtz, L.T., 1945. Determination of total organic and available forms of phosphorus in soils. Soil Sci. 59: 39-45.

Bremmer, J.M. and Malvaney, C.S. 1982. Nitrogen In: A.I.Page, R.H. Mille and D.R. Keeney (Eds), Methods of soil analysis 2, Agronomy monograph No. $92^{\text {nd }}$ Edition American Society of Agronomy Madison, WI. U.S.A. Pp: 159-165.

Chapman, H.D., 1965. Cation exchange capacity. In: C.A. Black, L.E. Ensminger and F.E. Clark (Eds). Methods of soil analysis. Agronomy. 9: 891-901. Am. Soc. Agro., Inc., Madison, Wisconsin.

Dixon, A.G.O. and C.L A. Asadu. 2001. Performance of seven crop combinations in two soils of different land-use history in eastern Nigeria. Agro-Science Journal 2(2): 70-80.

FAO (Food and Agricultural Organization), 1983. Atlas of African Agriculture Guidelines: Land evaluation for rainfed agriculture. Soil bulletin No. 52. Rome: FAO

Flinck, A., 1973. The fertility of tropical soils under the influence of agricultural land use. Applied Science Development, 1:7-31.

Hudson, N., 1981. Soil Conservation. Batsford Academic and Educational Ltd: London.

Kang, B.T, and Juo, A.S.R., 1983. Management of low activity clay soils in tropical Africa for food crop production. Pp. 450-470. In: Beinroth, 
F.A., Neel, A., Ewaran, H. (Eds). Proceedings of the fourth international soil classification workshop. Kigali, Rwanda. Brussels, Belgium: ABOS-AGCD.

Lal, R., 1984. Soil erosion from tropical arable lands and its control. Advances in Agronomy 37, 183-248.

Lal, R., 1987. Managing the soils of Sub Saharan Africa. Science, 4(236): 1069-1076.

McLean, E.O., 1965. Aluminum. pp. 978-998. In: C.A. Black (Ed.). Methods of Soil Analysis. Agron. No.9. Part II. Am. Soc. Agron, Madison, Wisconsin. USA.

Mulongey, K. and R. Merck (Eds.), 1993. Soil organic matter dynamics and sustainability of tropical agriculture. John Wiley and Sons, Inc., New York. 392p.
SAS (Statistical Analysis System), 1985. SAS User's Guide: Statistics, Version. Statistical Analysis System Institute. Cary, NC.

Thomas, G.W. 1982. Exchangeable cations In: A.I.Page, R.H. Mille and D.R. Keeney (Eds), Methods of soil analysis 2, Agronomy monograph No. $92^{\text {nd }}$ Edition American Society of Agronomy Madison, WI. U.S.A. Pp: 159-165.

Walkley, A. and I.A. Black, 1934. An examination of the Degtjareff method for determining soil organic matter and a proposed modification of the chromic acid titration method. Soil Sci. 37: 29-38. 